\section{The production of ignorance}

\author{
John Launer
}

If you have never heard of the word agnotology, there is probably a good reason. It means the study of the deliberate manufacture of ignorance or doubt, including the spread of selective, inaccurate or misleading scientific data. Familiar examples in the scientific and medical fields include campaigns to persuade people that climate change has been exaggerated, that gun control will not reduce the number of murders, that vaccinations cause more harm than benefit, or that the link between smoking and cancer is still unproven. Such misinformation is also common in the political field, and this has probably always been the case. Anyone who is despondent about the assaults on truth in the recent parliamentary elections in the United Kingdom, or the last presidential contest in the United States, may find it salutary to read the comments of the great economist John Maynard Keynes on the British elections in 1931: "I cannot remember any election in which more outrageous lies were told by leading statesmen."

The word agnotology was first coined by the American historian of science Robert $\mathrm{N}$ Proctor, with the help of a linguist called Iain Boal. It draws on the Greek word agnosis, meaning 'not knowing' (as in 'agnostic'). By definition, misinformation is designed not to be identifiable as such. As the sociologist Linsey McGoey has pointed out, "we are doomed to miss the most successful cases." 2 Schools and universities generally focus on the production of knowledge rather than teaching students how to identify its evil twin, the propagation of ignorance. Hence it is perhaps unsurprising that even the name for this field of study remains largely unrecognised.

Ignorance through lack of sufficient knowledge is of course different from telling intentional falsehoods. ${ }^{3}$ It can be the starting point for scientific discovery, or a consequence of discretion. Few people would argue, for example, that instructions for making bombs should be widely shared, or that no-one should be allowed to keep some information about their personal lives private. Most ignorance

Associate Editor, Postgraduate Medical Journal, London, UK

Correspondence to Dr John Launer, London, UK; johnlauner@aol.com is probably harmless, simply because the range of knowledge that each of us needs to possess is infinitesimal, compared with what is knowable. At the same time, there is a good argument for understanding how ignorance can sometimes be propagated actively by groups who have a vested interest in doing so.

\section{PROMOTING IGNORANCE}

The methods for promoting ignorance intentionally are legion, and Robert Proctor has described many of these in a book on agnotology that he edited with another historian, Londa Schiebinger. ${ }^{4}$ One classic method relating to medical knowledge is summed up nicely in the words of a tobacco executive quoted in the book, who indiscreetly admitted: "Doubt is our product." Thus, for nearly 70 years since the deleterious effects of smoking were conclusively established, the cigarette industry has deployed a tremendous range of subtle - and not so subtle - tactics to suggest that there is room for disagreement on the issue. According to Proctor and Schiebinger, these tactics include "duplicitous press releases, funding of decoy research, establishment of scientific front organisations, manipulation of legislative agendas, organisation of 'friendly research' for publication in popular magazines, and myriad additional projects from the dark arts of agnotology." This duplicity continues to support the annual sale worldwide of over 5 trillion cigarettes, a significant proportion presumably being smoked by consumers who have succeeded in reassuring themselves that the jury is still out on the matter.

Although tactics like these are used when evidence of medical harm has been established, it may sometimes be more efficient to suppress such evidence in the first place. In 2004, the Lancet published a now famous paper showing that the pharmaceutical giant Glaxo Smith Kline had failed to release evidence that would have shown a significant increase in selfharming behaviour in children who took the antidepressant drug Paroxetine. ${ }^{5}$ An investigation in the United Kingdom lasting 4 years failed to lead to a prosecution, but in the United States the company was fined a record 3 billion US dollars. A similar scandal surrounded the withdrawal of the anti-inflammatory drug Vioxx, leading to 30000 law suits against its manufacturer, Merck, from patients who had suffered cardiovascular events as a result of taking it, or from their surviving families. ${ }^{6}$ No executive was punished in either scandal. These are only the two best known and most flagrant examples in the medical world of the production of ignorance through deliberate suppression of data. There are other examples, and some commentators believe there may be more unless there is legally enforced transparency of data more robust post-marketing surveillance, and criminal prosecutions.

\section{CHALLENGING IGNORANCE}

The advantages of sowing uncertainty or suppressing data in relation to drugs like tobacco or antidepressants are in one way obvious: financial gain for corporations and individuals, sometimes on a vast scale, but there may be wider causes. In her book "The unknowers: how strategic ignorance rules the world" ${ }^{2}$ Linsey McGoey puts forward a provocative argument that "market fundamentalism" allows financial and political elites to define the limits of what we are allowed to know, and what we are kept in ignorance about. By "market fundamentalism" she means the dogma that societies derive most benefit when governments do not interfere with the free operation of the market or the generation of profit. As the leading purveyors of ignorance, McGoey identifies a notional community of people she calls 'smarts' - public experts with a surfeit of credibility that allows them to define the truths that everyone is meant to accept - and an overlapping community of 'strongs', or authoritative leaders whose primary concern is with maintaining their positions. The latter, according to her analysis, apply any means they can, citing scientific facts at one moment if it suits them, and then undermining these by appealing to raw partisan, religious or xenophobic emotions when necessary. Such forms of ignorance production, in her view, allow elites to get away with murder, literally as well as metaphorically.

This polemical view of ignorance production and its central role in society will not meet with everyone's agreement. With technology becoming more advanced, the "strongs" and the "smarts" will no doubt have more opportunities to disseminate falsehoods in order to further their own ends. At the same time, easy access to information may also make it easier for ordinary citizens to check the facts and expose lies. As Trethewen 


\section{On reflection}

has argued in a recent editorial in $P M J,{ }^{8}$ doctors in particular may have to act as advocates, both individually and collectively, to counter misinformation. Increasingly, one of our most important professional roles may be in standing up for what is true and challenging ignorance, however it has arisen.

Twitter John Launer @JohnLauner

Funding The authors have not declared a specific grant for this research from any funding agency in the public, commercial or not-for-profit sectors.

Competing interests None declared.

Patient consent for publication Not required.
Provenance and peer review Not commissioned; internally peer reviewed.

(C) Author(s) (or their employer(s)) 2020. No commercial re-use. See rights and permissions. Published by BMJ.

\section{(D) Check for updates}

To cite Launer J. Postgrad Med J 2020;96:179-180.

Postgrad Med J 2020;96:179-180.

doi:10.1136/postgradmedj-2020-137494

\section{REFERENCES}

1 Quoted in Runciman D. The confidence trap. Princeton NJ: Princeton University Press, 2014: 85.

2 McGoey L. The unknowers: how strategic ignorance rules the world. London: Zed Books, 2019.
3 Dossey L. Agnotology: on the varieties of ignorance, criminal negligence, and crimes against humanity. Explore 2014;10:331-44.

4 Proctor RN, Schiebinger L. Agnotology: the masking and unmaking of ignorance. Stanford: Stamford University Press, 2008.

5 Whittington CJ, Kendall T, Fonagy P, et al. Selective serotonin reuptake inhibitors in childhood depression: systematic review of published versus unpublished data. Lancet 2004:363:1341-5.

6 Horton R. Vioxx, the implosion of Merck, and aftershocks at the FDA. Lancet 2004:364:1995-6.

7 Goldacre B, Lane S, Mahtani KR, et al. Pharmaceutical companies' policies on access to trial data, results, and methods: audit study. BMJ 2017;358:j3334.

8 Trethewey SP. Strategies to combat medical misinformation on social media. Postgrad Med J 2020;96:4-6. 